\title{
Genetics of coffee quality
}

\author{
Thierry Leroy $^{1 *}$, Fabienne Ribeyre ${ }^{1}$, Benóit Bertrand ${ }^{1}$, Pierre Charmetant ${ }^{1,4}$, Magali Dufour ${ }^{1}$, Christophe \\ Montagnon ${ }^{1}$, Pierre Marraccini ${ }^{1,2}$ and David Pot ${ }^{1,3}$.
}

${ }^{1}$ CIRAD (Centre de Coopération Internationale en Recherche Agronomique pour le Développement), TA 80/03, Avenue d'Agropolis, 34398 Montpellier Cedex 5, France ; ${ }^{2}$ EMBRAPA Recursos Genéticos e Biotecnologia CP 02372, 70770-900 Brasilia (DF), Brazil; ${ }^{3}$ Instituto Agronômico do Paraná, LBI-AMG, CP 481, 86001-970, Londrina, (PR), Brazil ; ${ }^{4}$ CIRAD/PROMECAFE, Aptdo 208-3011 Barva, Heredia, Costa Rica. *Corresponding author: thierry.leroy@cirad.fr

Coffee quality, in the present context of overproduction worldwide, has to be considered as a main selection criterion for coffee improvement. After a definition of quality, and an overview of the non genetic factors affecting its variation, this review focuses on the genetic factors involved in the control of coffee quality variation. Regarding the complexity of this trait, the different types of quality are first presented. Then, the great variation within and between coffee species is underlined, mainly for biochemical compounds related to quality (caffeine, sugars, chlorogenic acids, lipids). The ways for breeding quality traits for cultivated species, Coffea arabica and Coffea canephora are discussed, with specific challenges for each species. For $C$. arabica, maintaining a good quality in $\mathrm{F}_{1}$ intraspecific hybrids, introgressed lines from Timor hybrid, and grafted varieties are the main challenges. For C. canephora, the improvement is mainly based on intraspecific and interspecific hybrids, using the whole genetic variability available within this species. An improvement is obtained for bean size, with significant genetic gains in current breeding programmes. The content in biochemical compounds related to cup quality is another way to improve Robusta quality. Finally, ongoing programmes towards the understanding of the molecular determinism of coffee quality, particularly using coffee ESTs, are presented.

Key words: Coffea spp., biochemical compounds, candidate genes, ESTs, genetic breeding, marker-assisted selection, quality.

Genética da qualidade do café: No contexto do excedente de produção mundial, a qualidade do café tem sido considerada o principal critério de seleção no melhoramento dessa cultura. Após definir qualidade e fazer considerações sobre os fatores não genéticos afetando sua variação, esta revisão se concentra sobre os fatores genéticos envolvidos no controle da variação da qualidade do café. Em relação à complexidade desta característica, os diferentes tipos de qualidade são apresentados. Então, a grande variação dentro e entre as espécies de café é discutida, principalmente em relação aos caracteres bioquímicos relacionados com qualidade (cafeína, açúcares, ácidos clorogênicos, lipídeos). As maneiras para melhorar estes caracteres relacionados à qualidade nas espécies cultivadas Coffea arabica e Coffea canephora são discutidas, assim como os desafios específicos a cada espécie. Para C. arabica, manutenção da boa qualidade em híbridos interespecíficos $\mathrm{F}_{1}$, linhagens geradas por introgressão a partir do Híbrido do Timor, e enxertia de variedades são os principais desafios. Para C. canephora, o melhoramento é principalmente baseado em híbridos intra e interespecíficos, usando a variabilidade genética disponível nesta espécie. Um avanço é obtido com o tamanho da semente, com significante ganho genético em programas de melhoramento. O conteúdo de compostos bioquímicos relacionados com a qualidade da bebida é uma outra maneira de melhorar a qualidade do café Robusta. Finalmente, são comentados programas em andamento, direcionados para a compreensão do determinismo molecular da qualidade do café, particularmente usando ESTs de café.

Palavras-chave: Coffea spp., compostos bioquímicos, ESTs, genes candidatos, melhoramento genético, qualidade, seleção assistida por marcadores. 


\section{INTRODUCTION}

According to the current context of overproduction and low prices of the coffee market, improvement and valorisation of coffee quality could provide the coffee chain with a new impetus. In this context, the efficiency of integration of coffee quality as a main target in breeding programmes as opposed to its previous status as a secondary selection criterion (Van der Vossen, 2001), will be based on our ability to answer several questions:

i) What is quality?

ii) What are the factors that affect quality?

iii) What strategies have been used up to now to improve and/or maintain coffee quality and what types of results were obtained?

iv) What type of results can be expected through the use of the genomic toolkit?

Based on these questions, this paper will be divided in four parts. First, we will try to define more precisely what quality is. From agronomy to organoleptic quality and health, the main criteria affecting quality will be defined. In the second part, we will examine the sources of variation in quality. In the third part, the strategies used and the results achieved by traditional genetic breeding techniques regarding coffee quality will be set out for both cultivated species and interspecific hybrids. In the last part, the recent resources available through the development of the genomic toolkit and their applications towards the identification of the genes involved in the determinism of coffee quality will be presented.

\section{What is coffee quality?}

Quality is a trait difficult to define. According to any dictionary, it is an "inherent or distinguishing characteristic". The International Organization for Standardization (ISO) describes quality as "the ability of a set of inherent characteristics of a product, system or process to fulfil requirement of customers and other interested parties" (ISO, 2000). These inherent characteristics can be called "attributes".

For coffee, the definition of quality and the attributes considered have probably evolved through the centuries. Nowadays, this definition varies along the production-toconsumer chain:

- at the farmer level: coffee quality is a combination of production level, price and easiness of culture;

- at the exporter or importer level: coffee quality is linked to bean size, lack of defects, regularity of provisioning, tonnage available, physical characteristics and price;
- at the roaster level: coffee quality depends on moisture content, stability of the characteristics, origin, price, biochemical compounds and organoleptic quality. It should be noted that each consumer market or country may define its own organoleptic qualities;

- at the consumer level: coffee quality deals with price, taste and flavour, effects on health and alertness, geographical origin, environmental and sociological aspects (organic coffee, fair trade, etc).

The ISO (2004a) defined a standard for green coffee quality (ISO 9116 standard). It requires several pieces of information, like the geographical and botanic origins of the coffee, the harvest year, the moisture content, the total defects, the proportion of insect-damaged beans and the bean size. These ISO standards define methods of measurement for several of these qualities: defects, moisture content, bean size, some chemical compounds and preparation of a sample to perform cup tasting.

The researcher has to take into account all these aspects in his work on quality. We will detail four important quality characteristics in order to illustrate the problems and constraints one has to face to improve coffee quality. Three of them, i.e. moisture content, physical and organoleptic qualities are used all along the production chain whereas the last one, i.e. "health quality" is a characteristic more and more taken into account by the consumers.

\section{A. Moisture content}

Moisture is an important attribute and indicator of quality. A market survey conducted by APROMA in Europe in 1998-1999 for the common fund for commodities concluded that for Robusta coffee beans the most important defect for a trader or a roaster is the moisture content. A high moisture content of the beans is a lost of material and leads to physical and sensorial defects. If the beans are too wet (above $12.5 \%$ moisture), they will mould easily during storage. If the beans are too dry (below $8 \%$ moisture), they will loose flavour. The moisture content influences the way coffee roasts and the lost of weight during roasting. Green coffees with low moisture content tend to roast faster than those with high moisture content. The ICO resolution 407 recommends that coffee should not be exported when outside of these limits as assessed by the ISO 6673 method. Some exceptions are permitted for some speciality coffees like the Indian monsooned coffees. 


\section{B. Physical quality}

Since October $1^{\text {st }}, 2002$, the International Coffee Organization (ICO, 2002) implemented a Coffee Quality Improvement Program (CQP) with recommendations to exporting countries. It is not recommended that coffee be exported with the following characteristics: for Arabica, in excess of 86 defects per $300 \mathrm{~g}$ sample (New York green coffee classification/Brazilian method, or equivalent); and, for Robusta, in excess of 150 defects per 300 grams (Vietnam, Indonesia, or equivalent classification). Also, ISO (2004b) has established a standard (ISO 10470) that describe defects as:

- Foreign materials of non-coffee origin;

- Foreign materials of non-bean origin, such as pieces of parchment or husks;

- Abnormal beans for shape regularity/integrity;

- Abnormal beans for visual appearance, such as black beans;

- Abnormal beans for taste of the cup after proper roasting and brewing.

Bean size, defined as grade from a commercial point of view, is an important factor since price is related to the coffee grade (small beans of the same variety can bring lower prices). Roasting should ideally be carried out with beans of the same size. When unevenly sized beans are roasted, the smallest tend to burn and the largest tend to be under-roasted, affecting the visual appearance of the beans and, more importantly, the cup quality (Barel and Jacquet, 1994).

\section{C. Organoleptic quality}

When assessing organoleptic quality, one has to take into account that consumers have a specific taste according to their nationality which leads to an unreliable definition of organoleptic quality. For example: Germans and Swedes prefer coffee lighter and more acidic than Italians; in Greece, Lebanon or the north of France, people go for the « rio » taste (a specific taste due to a chemical compound: trichloroanisol). In addition, organoleptic characteristics must be stable, especially for the roaster and the consumer.

The assessment of coffee organoleptic quality is a difficult task. The smell of the ground roasted coffee before water is added is sometimes called fragrance, then, one can smell the aroma, evaluate the body and perceive taste and flavours. Organoleptic quality measurement relies overall on sensory evaluation. Two types of analysis are commonly used. The first one, named "hedonic analysis", evaluates the preference of consumers. It has to be performed on a panel of at least 60 spontaneous assessors that represent the population of whose preference is sought. The second method is termed "descriptive analysis". Trained assessors can discriminate coffees using, for example, a triangular test. Three cups of coffee are served, two cups containing the same coffee. The assessor has to determine which cup is unique. Expert assessors can describe a profile. It is a complex procedure which uses some specific descriptors. There are some existing glossaries (Lingle, 1986; ITC, 2002; ICO, 2004), but ISO will soon elaborate a list of descriptors specific for coffee (Prodolliet, 2005). Expert assessors (at least 5) have to be trained to use the vocabulary. Assessment of coffee organoleptic quality is an extremely demanding exercise; indeed the flavour obtained in a coffee cup is the result of multiple aromatic compounds present in the coffee (more than 800 in the roasted coffee).

Since measurement of the composition in 800 aromatic compounds present in roasted coffee is not a viable method to assess coffee organoleptic quality, development of indirect predictors of coffee organoleptic quality is underway. These predictors include quantification of chemical compounds present in green coffee (sugars, lipids, proteins, chlorogenic acids, and methylxanthines) via the traditional wet chemistry method and indirect methods like Near Infrared spectra (Bertrand et al., 2005b). The development of such easy to use and efficient tools should allow large scale phenotyping, a key component towards the implementation of breeding strategies for organoleptic quality in coffee.

\section{D. Health quality}

For consumers, one of the most important components of quality for alimentary goods is food safety. Coffee contains a lot of molecules that can have an effect on health and alertness. Some of them are naturally present in coffee beans or derived from biochemical reactions occurring during roasting, whereas others like Ochratoxine A (OTA) and residues of pesticides are external compounds independent of the chemical composition of coffee beans.

The level of pesticide residues is usually low in coffee (FDA, 2002). Ochratoxin A (OTA) is a toxic mycotoxin. Mycotoxin can be produced by several mould species and can be found particularly in cereals. In coffee, OTA is produced by Aspergillus niger, A. carbonarius and A. ochraceus. It has been shown to cause kidney damage and tumours in test animals. It is classified as possibly carcinogenic to humans.

In terms of chemical compounds present in coffee beans, several of them are known to have consequences on health. 
The one chemical component that has received the most scientific scrutiny is caffeine. Most consumers look for its stimulating effect on brain activity. Despite its positive effect on alertness, caffeine also has some possible implications in diseases like hyper cholesterol and cancers. Coffee also contains chlorogenic acids, melanoidins, and other unknown substances which are identified as strong antioxidants. Diterpens specific to Coffea species (Cafestol and Kahweol) have also been shown to present some hyper cholesterol properties associated with possible antioxidant properties. To summarize, despite the knowledge acquired on a few components in terms of consequences on health, very little is known of the other constituents that make up $98 \%$ of roasted coffee beans.

As a conclusion to this first part, no simple definition can be given for coffee quality, whatever the level of the interlocutor in the coffee market chain. Different components are included under the quality term. Nevertheless, in addition to this level of complexity, a second one can be added: coffee quality is highly variable depending on environmental, technical and genetic factors.

\section{Non genetic sources of variation for quality}

As presented in the previous part, coffee quality involves several components. These traits are subject to different sources of variation. Some of them are exclusively dependent on the harvest and postharvest procedures (moisture content, number of defects in coffee batches for instance) whereas others will depend on pedo-climatic conditions ("terroirs"), physiological and genetic factors.

\section{A. Harvest and post harvest effects on quality}

It is widely agreed that traditional hand-picking and husbandry labour, as opposed to mechanical harvest, produce the best quality green coffee by decreasing the percentage of defects in coffee batches. Then, depending on the postharvest process, strong consequences on coffee quality can be observed. For instance, dry processing is generally avoided for quality samples as it enhances bitterness in the liquor (Barel and Jacquet, 1994).

Once the beans have been harvested and prepared, the organoleptic quality is affected by the roasting. According to the profile of temperature and length of roasting the tastes and flavours perceived in the beverage will be different.

\section{B. Pedo-climatic effect on quality}

Climate, altitude, and shade play an important role through temperature, availability of light and water during the ripening period. Rainfall and sunshine distributions have a strong influence on flowering, bean expansion, and ripening. For instance, chlorogenic acids and fat content have been found to increase with elevation in C. arabica. The role of soil types has been well studied. It is generally admitted that the most acidic coffees are grown on rich volcanic soils (Harding et al., 1987).

\section{C. Physiology effect on quality}

Tree physiology, plant age, and period of picking all interact to produce the final characteristics of the product. Indeed it was found that tree age, location of the fruits within the tree, and fruits-to-leaves ratio had a strong influence on the chemical content of green beans (Bertrand, 2002; Vaast et al., 2006).

Maturation also has a strong influence on coffee quality. Guyot et al. (1988) showed for C. canephora that yellow or green cherries picked at the end of the picking season contain beans with a higher maturity level than red cherries picked at the start of the picking season. This can be seen in bean size, chemical contents, and cup quality. On the other hand, for $C$. arabica in Costa Rica, early picking of red cherries gives the best coffee (Bertrand, 2002).

In summary, coffee quality is a complex trait that relies on multiple factors. Beside the non-genetic factors that have been presented, the role of genetics is far from being negligible. The coffee breeding strategies that take into account the quality attributes will be presented in the next paragraph.

\section{Genetic breeding for quality}

If harvest, post harvest procedures and the physiology of the plant affect coffee quality, its genetic origin (species and genotype) will also greatly influence coffee quality. This third part will be divided in three subparts. In the first, a rapid overview of the variation observed at the interspecific and intraspecific level will be presented. In the second and third parts, the breeding strategies developed in both $C$. arabica and $C$. canephora will be exposed.

\section{A. Genetic variation for quality}

The Coffea genus includes more than one hundred different species between which a large variation in terms of chemical composition is observed (Clifford, 1985). Up to now, $C$. arabica and $C$. canephora have received the most attention due to their commercial predominance. Large variations between these two species are observed for most of their chemical compounds, as shown in table 1. 
Significant variation exists also at the within species level. If the variation within C. canephora is continuous, within $C$. arabica the variability of quality takes a particular pattern with mutants presenting specific quality attributes, such as Caturra (dwarf, high productivity sometimes linked to a drop in quality) or Maragogype (very large beans, low productivity but highly priced on the marked). In addition, some mutants have been identified, especially regarding low caffeine contents, such as $C$. arabica variety Laurina (0.6\% $\mathrm{dm})$, and, more recently, in Brazil, an Ethiopian origin with traces of caffeine (Silvarolla et al., 2004).

\section{B. Breeding for quality in $C$. arabica}

Among C. arabica genotypes, three groups of plants can be identified: the wild genotypes from the Sudan-Ethiopian region, the cultivated non-introgressed lines (Typica and Bourbon types), and the introgressed varieties, mainly constructed from Timor hybrid genotypes.

Coffee produced by $C$. arabica is considered to be a good quality coffee. This characteristic is clearly established for classical varieties like Caturra, Mundo Novo, and other pure lines obtained from pedigree selection. Since breeding programs have selected $\mathrm{F}_{1}$ hybrids, introgressed lines or rootstocks, some quality factors may have been modified. The following paragraphs present the possible modifications of quality due to these breeding strategies.

Introgression and quality: In the case of Arabica coffee, pedigree selection has been recommended for transferring genes of resistance from the Timor hybrid, which is a natural hybrid derived from a cross between $C$. $\operatorname{arabica}(2 \mathrm{n}=2 \mathrm{x}=44)$

Table 1. Variation of chemical components of green beans in Coffea arabica and Coffea canephora.

\begin{tabular}{lcc}
\hline Component & C. arabica & C. canephora \\
\hline $\mathrm{pH}$ & $5.26-6.11$ & $5.27-6.13$ \\
Mineral content * & $3.5-4.5$ & $3.9-4.5$ \\
Fat content & $13-17$ & $7.2-11$ \\
Caffeine content * & $0.7-2.2$ & $1.5-2.8$ (average \\
& (average 1.4) & 2.2 ) \\
Chlorogenic acids & $4.80-6.14$ & $5.34-6.41$ \\
content $*$ & & \\
Trigonelline* & $1-1.2$ & $0.6-1.7$ \\
Oligosaccharides* & $6-8$ & $5-7$ \\
Total polysaccharides* & $50-55$ & $37-47$ \\
\hline
\end{tabular}

*\% dry matter (dm)

Source: (Wintgens, 2004) and $C$. canephora, $(2 \mathrm{n}=2 \mathrm{x}=22)$. Since the second half of the $20^{\text {th }}$ century, most breeding programmes implemented throughout the world (Brazil, Colombia, Kenya, Costa Rica, Honduras) have transferred resistance to rust (Hemileia vastatrix Berk. and Br.), root-knot nematodes (Meloidogyne sp.) and Coffee Berry Disease (Colletotrichum kahawae sensu Hindorf) from the Timor hybrid to cultivars of $C$. arabica. Several cultivars (i.e. cv. 'Costa Rica 95', cv. 'Obatã', cv. 'IAPAR59') are fixed lines obtained after several generations of pedigree selection. It has been estimated that several hundred thousand hectares have been planted with these new varieties. Given this success, it can be expected that breeding of the Arabica species for resistance to pests and diseases will be based for some time on crosses derived from the Timor hybrid. The amount of alien genetic material, introgressed in many Arabica lines, ranges from $8 \%$ to $27 \%$ of the $C$. canephora genome (Lashermes et al., 2000a).

It thus seems likely that the introgression process has not been restricted to resistance traits but could also involve genes implicated in the genetic determinism of other traits. Based on organoleptic evaluation, introgressed lines of Arabica were found to produce good beverage quality (BQ) that was similar to the non-introgressed standard (Fazuoli et al., 1977; Owuor, 1988; Castillo, 1990; Moreno et al., 1995; Puerta, 1998, 2000). However, most coffee buyers claim that new introgressed varieties have a poorer BQ than the 'Caturra' standard. By linking the amount of alien genetic material as estimated by AFLP analysis in Timor hybrid-derived lines, with beverage quality and chemical composition of beans, we have found that these conclusions need to be moderated. For the cultivars CR95 and 'Veranero' and for some lines undergoing selection it seems there is a drop in quality due to introgression. That was the case with line T17924 which displayed significant differences from the non-introgressed controls for most of the chemical contents (trigonelline, sucrose and chlorogenic acids), and for beverage acidity and preference related to a standardized control (Bertrand B et al., 2003). However, there were also highly introgressed lines that revealed no difference from the non-introgressed controls. Such was the case with lines T17934 and T17931, which did not differ for either the chemical content or the $\mathrm{BQ}$. As the latter display genetic resistances to coffee leaf rust and $M$. exigua, it was concluded that the presence of these resistance genes has no pleiotropic effects on beverage quality. This was an encouraging result for the future of genetic improvement programmes based on the introgression of resistance genes from C. canephora via the Timor hybrid. 
However, to be more effective and avoid undesirable introgressed fragments suspected of having a negative effect on $\mathrm{BQ}$, selection could be assisted by specific markers of resistance to pests/diseases (Lashermes et al., 2000b).

On the other hand, this programme could be more efficient if it was possible to identify chemical compounds of which variations are highly correlated to quality defects due to introgression.

$F_{1}$ hybrids and beverage quality: Since the 1980s, several researchers have proposed the creation of hybrid varieties to help in increasing genetic diversity, notably by crossing wild Ethiopian origins with introgressed or non introgressed varieties (Charrier, 1978) and to exploit heterosis between genetic groups (Walyaro, 1983; Van der Vossen, 1985; Charrier and Berthaud, 1985). Ethiopian origins provide resistance to nematodes (Anzueto et al., 2001), partial resistance to leaf rust (Gil et al., 1990) and resistance to CBD (Van der Vossen, 2001) and likely a better beverage quality. As regards heterosis in the species, Carvalho and Monaco (1969), Walyaro (1983), Ameha (1990), Bellachew (1997) and then Cilas et al. (1998) demonstrated its existence by intercrossing. In $C$. arabica, heterosis calculated on the basis of the best parent was evaluated from crosses between different genetic pools. The heterosis observed by different authors varied from $10 \%$ to $40 \%$ (Ameha, 1990; Carvalho and Monaco, 1969; Fazuoli et al., 1993; Walyaro, 1983; Netto et al., 1993), with the notable exception of the heterosis reported by Cilas et al. (1998) which reached over $200 \%$. The heterosis found in Central America (22.0 to 47.0 \%) was globally around the same magnitude as that observed by the majority of authors.

In Central America or in Ethiopia, the yield differences between the parental lines and the hybrids were not explained by the yield components, such as the number of fruits per node or by the weight of 100 beans which were identical for both populations. Finally, heterosis seemed to be permanently reflected in longer primary branches (Bertrand et al., 2005a).

The $\mathrm{F}_{1}$ hybrid population showed lower fertility than the population of lines. Under Central American conditions, the difference in fertility rate was from 1.2 to $6.3 \%$ of floating fruits. In coffee, the number of seeds per fruit depends on ovule fertility (Louarn, 1992). Neither could heterosis be explained by better fertility, since hybrid fertility was even lower than that of the lines.

No clear differences were found for bean chemical contents and cup quality in sensory evaluations comparing $\mathrm{F}_{1}$ hybrids with traditional cultivars ('Bourbon') under various edapho-climatic conditions and at different elevations (Bertrand et al., 2006). $F_{1}$ hybrids appeared in turn to be inferior, similar, or superior to traditional cultivars for certain attributes, such as acidity, or aroma. Regarding the standardized control, $\mathrm{F}_{1}$ hybrids were equivalent or superior to traditional cultivars. For caffeine, as for trigonelline, the hybrids did not differ from the traditional varieties. The hybrids showed a tendency to be slightly richer in chlorogenic acids than the traditional varieties. For traditional cultivars, lipid content varied with elevations (i.e. respectively lower at lower elevations and higher at higher elevation). On the other hand, elevation did not seem to influence fat contents for the $\mathrm{F}_{1}$ hybrids. These new varieties that produce 30 to $70 \%$ more than traditional varieties were exceptionally vigorous. Higher vigour resulted in better nutrient supply to the fruits, whatever the elevation. The use of $F_{1}$ hybrids should thus contribute to reducing variations in the fat content of coffee beans, and at the same time reduce variations in beverage quality.

Rootstocks and beverage quality: In order to avoid nematode damage to roots of $C$. arabica, a common practice is interspecific grafting on $C$. canephora. The performance of two cultivars (Caturra and T5175) was evaluated on four rootstocks: C. canephora ('T3561' and 'T3751'), C. liberica var. Liberica and C. liberica var. Devewrei, over 5 years in Costa Rica (Bertrand et al., 2001). Grafting did not affect evaluated chemicals, such as caffeine, fat and sucrose contents. However, the two $C$. liberica rootstocks significantly reduced aroma and bean size. This poor performance of $C$. liberica was explained by partial incompatibility, observed on tissues at the graft level.

\section{C. Breeding for Robusta coffee quality}

Robusta is known as less aromatic and richer in caffeine than Arabica coffee. The improvement of cup quality could be performed by genetic breeding, but up to now quality has not often been considered before the end of the selection cycle (Charrier and Berthaud, 1988).

The main quality traits that could be improved for Robusta coffee are the following: bean size and extractable soluble solids regarding technological qualities, sugars, caffeine, trigonelline, lipids, chlorogenic acids for biochemical traits, and beverage quality. In this paragraph, we will first discuss the variability of quality components in Robusta coffees. Then, their inheritance and the genetic correlations 
between traits will be presented. Finally, we will present the two ways of improvement of Robusta quality: via intraspecific selection or interspecific crossing programs.

Among C. canephora genotypes, two main genetic and geographic groups have been identified: the Guinean group from western Africa, and the Congolese group from central Africa (Berthaud, 1986). Further studies divided the Congolese group in four subgroups (Montagnon et al., 1992; Dussert et al., 1999).

Variability for quality traits: In a breeding perspective, two components need to be considered. Phenotypic variability and heritability of the traits need to be carefully evaluated in order to appreciate the potential consequences of selection on these traits.

In their paper, Ky et al. (2001a) describe the diversity observed in some quality precursors like caffeine, trigonelline, chlorogenic acids and sucrose for C. canephora accessions. This species presents a high variability for these traits. Values vary from 4.05 to $7.05 \%$ of the dry matter $(\mathrm{dm})$ for sucrose, and from 0.75 to $1.24 \% \mathrm{dm}$ for trigonelline. For caffeine content, values from $1.0 \%$ to 5.0 $\%$ have been observed. The authors point out that for one of the chlorogenic acids the Congolese and Guinean origins present different values, but that for most compounds, the geographical origin of the plants within the genetic groups is the main factor of variability. Regarding cup quality, Moschetto et al. (1996) evaluated the differences between genetic groups. The results show significant differences between the groups for preference, aroma, acidity, body and bitterness. Guinean genotypes can be considered as inferior to the Congolese ones for preference and aroma. They also found some variability within the Congolese group.

Heritability, genetic correlations and genetic gains: In 1998, Montagnon et al. studied the genetic correlations between the yield and several quality traits, including fat content, sucrose, trigonelline, caffeine and cup tasting components. A factorial crossing design with two parents from the Congolese group crossed with 14 genotypes from the Guinean group was used to evaluate the genetic parameters of these compounds. First, they observed that variation of yield and quality traits are independent. This result is very important, meaning that quality can be improved without effect on yield.

In the same paper, the authors studied the heritability (narrow sense) for some traits related to quality within $C$. canephora species. The results are presented in table 2 .
For traits presenting high values of heritability, like fat content, bean weight or caffeine, an efficient selection could be obtained in the crossing schemes by a good choice of parents with favourable values for these traits. For traits like trigonelline, chlorogenic acids or sucrose, with intermediate values, Marker Assisted Selection (MAS) should be an efficient way for their improvement.

Other results on interspecific hybrids suggest a high value (0.71) for heritability of trigonelline content (Ky et al., 2001b), with a maternal inheritance. For sucrose content, while Montagnon et al. (1998) indicated that this trait could be difficult to improve, since $\mathrm{h}^{2}$ is low and environmental effects are high, Ky et al. (2000a, b) found an additive transmission among their interspecific hybrids, with the possibility of choosing parents for its improvement.

However, it is important to note that the values of heritability obtained for interspecific hybrids have a different meaning than the one obtained at the intraspecific level. The different species have probably fixed along their evolution specific alleles at some genes controlling the variability of quality components; as a consequence the genetic determinism of quality variation at the interspecific level is simplified compared to intraspecific crossing schemes. Nevertheless, these results are of interest, since they can indicate candidate genes potentially involved in the variation of coffee quality components at the intraspecific level.

As also shown by Montagnon et al. (1998), fat content and sucrose content are negatively correlated. A combined selection for these two traits should be then very difficult.

In their study on cup tasting from samples of the two genetic groups, hybrids and commercial clones, Moschetto et al. (1996) indicated good linear correlation coefficients between preference, and some factors like acidity and aroma. Since these two characteristics are easier to define and select, they could be used as selection criteria for Robusta organoleptic quality.

Table 2. Heritability (narrow sense) estimated from a factorial crossing desig $n$.

\begin{tabular}{lc}
\hline Trait & $\mathrm{h}^{2}$ (narrow sense) \\
\hline Sucrose content & 0.11 \\
Fat content & 0.74 \\
Trigonelline & 0.38 \\
Caffeine & 0.80 \\
Chlorogenic acids & 0.36 \\
Bean weight & 0.73 \\
\hline
\end{tabular}


Interspecific and intraspecific hybrids: Interspecific hybrids mainly involve three species: C. arabica, C. congensis and $C$. liberica. The $\mathrm{F}_{1}$ hybrids between $C$. arabica and C. canephora, called Arabusta, produce fair cup quality coffee, but they appeared agronomically unsuitable due to their lower fertility and unstable yields in lowlands (Capot, 1972; Charmetant et al., 1992). These hybrids could be an alternative for producing coffee of good quality at medium altitude, where Arabica coffee is not really adapted.

The hybrids between $C$. canephora and $C$. congensis have been developed in Madagascar and Ivory Coast. Some of them are distributed to the growers in Madagascar. They present a larger bean size than Robusta, and their organoleptic quality is good (Moschetto et al., 1996), compared to some C. canephora origins.

Hybrids between $C$. canephora and C. liberica have also been obtained. Since $C$. liberica has been cultivated since the beginning of the $20^{\text {th }}$ century, it is known that coffee produced by this species is less bitter and presents larger beans than Robusta coffee. Some high yielding plants have been selected in a second generation of back crosses of such hybrids to the $C$. canephora parent (Yapo et al., 2003); they could be integrated in selection programs in Ivory Coast, and distributed to the growers for the improvement of coffee quality.

Other species like C. pseudozanguebariae (Bertrand C et al., 2003) could be used as sources of improvement for $C$. canephora. This species is caffeine free and presents a high level of trigonelline and sucrose. Some interspecific hybrids using this species have been produced (Barré et al., 1998; Ky et al., 1999; 2000a, b; 2001b), but they remain unusable from an organoleptic point of view.

Regarding intraspecific breeding programs, the main recent work has been developed in Ivory Coast (for review see Montagnon, 2000). Since two main genetic groups (Congolese and Guinean) have been identified within this species (Berthaud, 1986) a reciprocal recurrent selection programme has been developed, based on the high agronomic value of the hybrids between both groups. It has to be noted that further studies (Montagnon et al, 1992; Dussert et al., 1999) have pointed out more subgroups in the Congolese group. In this programme, initiated in 1984, the improvement for quality has been introduced in the different steps of the cycle of selection: base populations used for the programme, selected hybrids and clones. Bean size has been considered in the first step of selection (base populations), and then caffeine content and cup tasting were considered as the final choice of hybrids or clones to be distributed to the growers.

In Brazil, for the selection of Conilon varieties (Bragança et al., 2001), bean size and time to fruit maturation were two quality criteria used for the choice of new varieties.

Recent studies on Robusta quality pointed out that genetic gains are possible for some traits like caffeine and bean size (Montagnon, 2000) in the present schemes of selection. Concerning biochemical traits and determinants of organoleptic quality, a selection could be efficient with the determination of molecular predictors. These molecular predictors would allow reducing the length of the selection cycles and the cost of phenotypic evaluations. In that sense, a good knowledge of the genomics for both species is a prerequisite condition.

It would be extremely useful to know more of the organisation of Arabica and Robusta genomes. The comprehension of their organisation and diversity and their specific differences will undoubtedly provide the coffee scientific community with a new understanding of coffee quality development. In the following part, the interest of molecular studies towards the comprehension of coffee quality will be presented.

\section{Genomics and quality: towards the identification of genes related to quality}

The identification of quality related genes is one of the main objectives of several coffee research groups around the world. This constitutes an absolute prerequisite for the development of efficient and rapid quality breeding strategies based either on marker-assisted selection (MAS), or on genetic modification approaches (GMO, see Pereira et al., Coffee Biotechnology, in the same issue). These two strategies, although they both aim at improving coffee quality, require different types of understanding. Although identification of a DNA fragment as a structural or a regulatory gene in a biosynthetic pathway leading to a quality precursor can "easily" be valorised by GMO construction, information like its level of nucleotide variation in natural populations and the links between the polymorphisms detected and the variability of the quality precursors need to be carefully verified before starting a marker assisted strategy.

Up to now, only a limited number of publications dealing with the identification of genes involved in the molecular determinism of coffee quality is available (see Castro and Marraccini, in this issue). In addition, most of them are exclusively linked with the carbohydrate, chlorogenic acids and caffeine metabolism. In a first step, an overview of the 
results currently available on the molecular determinism of quality will be provided. In a second step, the different possibilities of direct use of the EST (Expressed Sequenced Tag) resources developed around the world (Brazilian Genome Project: www.lge.ibi.unicamp.br/cafe/, see also Vieira et al., in this issue; Trieste University www.coffeedna.net; NestléCornell EST Sequencing project: http://sgn.cornell.edu (Lin et al., 2005) will be presented.

\section{A. Molecular determinism of coffee quality: What do we currently know?}

Development of neutral markers: Although not directly and exclusively linked to the comprehension of the molecular determinism of coffee quality, the efforts provided by the coffee research community towards the development of co-dominant and multiallelic molecular markers spread all over the coffee genome (Combes et al., 2000; Dufour et al., 2001; Baruah et al., 2003; Moncada and Mc Couch, 2004; Poncet et al., 2004; Bhat et al., 2005) will undoubtedly benefit this field of research. Indeed, the availability of these markers will allow the analysis of population structure and the development of genetic maps, two pre-requisites towards the identification of the genes responsible for the natural variation of coffee quality.

Genetic map construction: Several genetic maps are already available. Lashermes et al. (2001), Paillard et al. (1996) and Crouzillat et al. (2004) developed genetic maps of $C$. canephora. In parallel several interspecific genetic maps were built (Coulibaly et al., 2003: C. canephora x C. heterocalix; Ky et al., 2000b: C. pseudozanguebariae x C. liberica; N'Diaye, 2005: C. liberica x C. canephora).

The development of $C$. arabica genetic maps is less advanced due to its polyploid status and reduced diversity. Nevertheless Pearl et al. (2004) recently obtained a genetic map of a cross between Catimor and Mokka cultivars.

The pursuit of the genetic mapping efforts and the alignment of the different genetic maps using transferable markers like SSR (Simple Sequence Repeat) or candidate genes will provide the coffee research community with useful tools to identify the genomic regions involved in the variability of quality, a first step toward the identification of the genes involved in the natural variability of coffee quality.

For the moment, only interspecific QTL (Quantitative Trait Loci) detected in a cross between C. liberica 'dewevrei' and $C$. pseudozanguebariae have been published: for trigonelline content this was identified on the linkage group
G (Ky et al., 2001b), for fructification time on the linkage group E (Akaffou et al., 2003) and finally for chlorogenic acid content on the linkage group A (Campa et al., 2003). QTL mapping of coffee quality related traits in C. canephora is currently underway within the EU-funded project IQAR, ICA4-CT-2001-10068.

Candidate genes for coffee quality: In terms of quality, the coffee genetics community benefits from the work initiated by several teams on the molecular physiology of the precursors of quality (for review in this issue, see Ashihara for caffeine, Redgwell et al. for carbohydrates, Speer et al. for lipids, Clifford et al. for phenolic compounds) and on seed development (see Castro and Marraccini in this issue). These results provide the coffee genetics community with some of the genes encoding the enzymes of key metabolic processes in terms of quality. These genes are biological candidate genes possibly controlling the variability of coffee quality.

Once the specificity of expression of the gene in a particular biosynthetic pathway and in a particular organ is acquired, no additional results are required before developing a GMO strategy. When considering a marker assisted breeding approach additional verifications are compulsory.

Candidate gene polymorphism and coffee quality variability: Only one link between candidate gene polymorphism and coffee quality has currently been reported in the literature. In an interspecific cross between $C$. liberica 'dewevrei' and $C$. pseudozanguebariae, Campa et al. (2003) found a statistical link between the CCoAOMT (3-O-methyltransferase) polymorphism and chlorogenic acid content. Such a result, although it does not provide unambiguously a "causeconsequence relationship", provides an indication of the potential involvement of this gene in the genetic variability of chlorogenic acid content. Mapping of genes involved in the sucrose biosynthesis pathway is also underway in $C$. canephora (T. Leroy, unpublished data).

\section{B. Coffee ESTs: towards an acceleration of coffee quality molecular determinism comprehension}

The recent development of large EST sequencing projects should now speed up the identification of putative genes for quality traits, involved either in important biochemical pathways (caffeine, chlorogenic acid and trigonelline contents) or directly linked to important agronomical characteristics.

First, the availability of this genomic resource will allow the identification of SSR markers located in ESTs spread all 
over the Coffea genomes. These markers will be useful for population structure analysis and genetic mapping. Furthermore, they will allow the mapping of functional genomic sequences.

In addition, the major contribution of this resource to the comprehension of the molecular determinism of coffee quality will be the possibility to develop whole transcriptome analysis (macro or microarrays). Such analyses will provide the coffee community with i) the biosynthetic pathway linked to the expression of quality and ii) the genes within this pathway which are important in terms of expression.

Different types of experiments can be proposed. In order to understand the effect of environment on coffee quality, a given genotype could be analysed in different pedo-climatic conditions to identify the biosynthetic pathways which are affected. For instance, several investigations have recently suggested that shading and altitude lead to a slight increase of fat content (Guyot et al., 1996; Decazy et al., 2003; Vaast et al., 2006), although it is not known which class of lipids (fatty acids, sterols and/or diterpens) was affected. The use of a same genotype cultivated in different geographical regions and environmental conditions should allow the identification of the biochemical pathways affected (Silva et al., 2005). Furthermore, the use of the natural diversity of coffee species available in germplasm collections (Van der Vossen, 2001) for diterpens (de Roos et al., 1997), caffeine (Ky et al., 2001a), trigonelline (Ky et al., 2001a, b; Campa et al., 2004), sucrose (Campa et al., 2004) and chlorogenic acids content (Ky et al., 1999, 2001a) could also be used as a natural source for these screening experiments. The analysis of natural coffee mutants of Arabica, like "Caturra" cultivars which arose from a mutation of "Bourbon" cultivars (Krug, 1949), should also be reinvestigated in the light of this new information. This should facilitate the identification of genes linked to some important traits, like those possibly responsible for caffeine deficiency (Silvarolla et al., 2004).

The EST resources will form, together with the development of BAC libraries reported for both $C$. arabica and $C$. canephora coffee species (Noir et al., 2004; Leroy et al., 2005), a new framework for the identification of genes involved in coffee quality. These molecular resources will provide access to the genomic organization and the fulllength genomic sequences of the candidate genes identified through transcriptome analysis. In this context, the $C$. canephora BAC library which was developed on a relatively good cup quality genotype (clone 126, see Moschetto et al., 1996) was used to analyze the genome organization (copy number) of sucrose-metabolizing enzymes (mainly sucrose synthase and invertases) in the C. canephora genome and allowed the cloning of the CcSUS1 gene, the first gene of this species coding for the sucrose synthase enzyme (Leroy et al., 2005).

\section{Conclusions and perspectives}

Coffee quality is a highly complex trait. Its definition depends on the position of the interlocutor within the production chain and its expression depends on a multifactorial determinism including pedo-climatic conditions, postharvest treatments and genetics.

Physiology and agronomic studies together with a better comprehension of the physical and biochemical consequences of the postharvest treatments has already yielded significant improvement of quality.

In terms of genetics, significant genetic variability for bean chemical composition and organoleptic characteristics exists at both the between and within species levels. As a consequence genetic gains for quality can be achieved either by interspecific hybridization strategies or within species strategies.

In C. arabica, which is known to present a good quality coffee, the main target is the improvement of resistances to pathogens and yield. In this context, in terms of quality, the main objective of the breeders is to maintain the quality level in genetic material introgressed with alien material presenting resistance to pathogens. The global level of introgression of alien genetic material does not seem to be linked to variation in quality. In this context, the work initiated by IRD aiming at identifying genes involved in the differences of bean chemical composition and fructification time in different Coffea species could serve as an example. In the future, efforts should be made towards the identification of genes involved in the differences of bean characteristics between C. arabica and C. canephora (QTL detection in a pedigree derived from a pure Arabica x canephora cross), since such data would allow for specific selection of genotypes carrying Arabica alleles at these genes. Nevertheless even without these molecular tools, significant results have already been obtained. $F_{1}$ hybrids allowed a significant improvement of yield (30-70\% more than traditional varieties) without affecting cup quality. Grafting of $C$. arabica cultivars on $C$. canephora rootstock in order to avoid nematode damage to roots did not modify bean characteristics and cup quality.

For C. canephora, interspecific hybrids with C. arabica, $C$. congensis and $C$. liberica presenting good beverage quality 
were obtained. At the within species level, significant values for heritability were observed for most bean characteristics leading to the achievement of significant genetic gains for bean size, caffeine content, organoleptic quality and maturation time.

Today the availability of a new set of genomic tools including genetic maps, EST and BAC libraries offers the opportunity to accurately decipher the genomic control of quality components (see Vieira et al., in this issue). These results should allow in the medium term the improvement of breeding efficiency in two different ways: marker assisted selection or gene transformation which was reported to function by several research groups (see Pereira et al. in this issue).

Acknowledgments: P. Marraccini received the financial support (DCSUR-BRE-4C5-008) of the French Embassy in Brazil.

\section{REFERENCES}

Akaffou DS, Ky CL, Barre P, Hamon S, Louarn J, Noirot M (2003) Identification and mapping of a major gene (Ft1) involved in fructification time in the interspecific cross Coffea pseudozanguebariae x C. liberica var. Dewevrei: impact on caffeine content and seed weight. Theor. Appl. Genet. 106:1486-1490.

Ameha M (1990) Heterosis and Arabica coffee breeding in Ethiopia. Plant Breed. 6:593-598.

Anzueto F, Bertrand B, Sarah JL, Eskes AB, Decazy B (2001) Resistance to Meloidogyne incognita in Ethiopian Coffea arabica accessions. Euphytica 118:1-8.

Barel M, Jacquet M (1994) La qualité du café: ses causes, son appréciation, son amélioration. Coffee quality: its causes, appreciation and improvement. Plant Rech. Dévelop. 1: 5-13.

Baruah A, Hendre PS, Rajkumar R, Rajendrakumar P, Aggarwal K (2003) Isolation and characterization of nine microsatellite markers from Coffea arabica L. showing wide cross-species amplifications. Mol. Ecol. Notes 3: 647-650.

Barre P, Akaffou S, Louarn J, Charrier A, Hamon S, Noirot M (1998) Inheritance of caffeine and heteroside contents in an interspecific cross between a cultivated coffee species Coffea liberica var dewevrei and a wild species caffeinefree C. pseudozanguebariae. Theor. Appl. Genet. 96: 306-311.

Bellachew B (1997) Arabica coffee breeding in Ethiopia: a review. In: $17^{\text {th }}$ International Scientific Colloquium on Coffee. Nairobi, pp.406-414.

Berthaud J (1986) Les ressources génétiques pour l'amélioration des caféiers africains diploïdes. ORSTOM, Travaux et documents $n^{\circ} 188$. ORSTOM, Paris.
Bertrand B, Etienne H, Eskes AB (2001) Growth, production, and bean quality of Coffea Arabica as affected by interspecific grafting: consequences for rootstock breeding. Hort. Sci. 36:269-273.

Bertrand B (2002) L'amélioration génétique de Coffea arabica L. en Amérique Centrale par la voie hybride $\mathrm{F}_{1}$. Montpellier, France, Ecole Nationale Supérieure Agronomique, $\mathrm{PhD}$ thesis.

Bertrand B, Guyot B, Anthony F, Lashermes P (2003) Impact of Coffea canephora gene introgression on beverage quality of C. arabica. Theor. Appl. Genet. 107:387-394.

Bertrand B, Etienne H, Cilas C, Charrier A, Baradat P (2005a) Coffea arabica hybrid performance for yield, fertility and bean weight. Euphytica 141:255-262.

Bertrand B, Etienne H, Lashermes P, Guyot G, Davrieux F (2005b) Can near-infrared reflectance of green coffee be used to detect introgression in Coffea arabica cultivars? J. Sci. Food Agric. 85:955-962.

Bertrand B, Vaast P, Alpizar E, Etienne H, Davrieux F, Charmetant P (2006) Comparison of bean biochemical composition and beverage quality of Arabica hybrids involving Sudanese-Ethiopian origins at various elevations in Central America. Tree Physiol. (in press).

Bertrand C, Noirot M, Doulbeau S, de Kochko A, Hamon S, Campa C (2003) Chlorogenic acid content swap during fruit maturation in Coffea pseudozanguebariae. Quantitative comparison with leaves. Plant Sci. 165: 1355-1361.

Bhat PR, Krishnakumar V, Hendre PS, Rajendrakumar P, Varshney RK, Aggarwal RK (2005) Identification and characterization of expressed sequence tags-derived simple sequence repeats markers from Robusta coffee variety " $\mathrm{C}$ x R" (an interspecific hybrid of Coffea canephora x Coffea congensis). Mol. Ecol. Notes 5:80-83.

Bragança SM, Siqueira de Carvalho $\mathrm{CH}$, Almeida da Fonseca AF, Ferrão RG (2001) Variedades clonais de café Conilon para o Estado do Espirito Santo. Pesq. Agropec. Bras. 36: 765-770.

Campa C, Noirot M, Bourgeois M, Pervent M, Ky CL, Chrestin H, Hamon S, de Kochko A (2003) Genetic mapping of a caffeoyl-coenzyme A 3-0-methltransferase gene in coffee trees. Impact on chlorogenic acid content. Theor. Appl. Genet. 107:751-756.

Campa C, Ballester JF, Doulbeau S, Dussert S, Hamon S, Noirot M (2004) Trigonelline and sucrose diversity in wild Coffea species. Food Chem. 88:39-44.

Capot J (1972) L'amélioration du caféier en Côte d'ivoire. Les hybrides «Arabusta ». Café Cacao Thé 26:3-18.

Carvalho A, Monaco LC (1969) The breeding of arabica coffee. In: Fewerda FP, Wit F (eds), Outlines of perennial crop breeding in the tropics. Misc. Pap. Agric. Univ. Wageningen 4:198-216.

Castillo Z (1990) Mejoramiento genetico del café en Colombia. In : Centro Nacional de Investigaciones de Café CENICAFE (eds) 50 años de Cenicafé, 1938-1988. 
Conferencias conmemorativas, Chinchina Colombia, pp 46-53.

Charmetant P, Le Pierres D, Yapo A (1992) Evaluation d'hybrides Arabusta $F_{1}$ (caféiers diploïdes doublés $\mathrm{x}$ Coffea arabica) en Côte d'Ivoire de 1982 à 1989. In: $14^{\text {th }}$ International Scientific Colloquium on Coffee. San Francisco, pp.422-430.

Charrier A (1978) Etude de la structure et de la variabilité génétique des caféiers. Bull. IFCC 14:1-100.

Charrier A, Berthaud J (1985) Botanical classification of coffee. In: Clifford MN, Wilson KC (eds), Coffee: botany, biochemistry and productions of beans and beverage, pp.13-47. Avi Publishing Company, Westport, Connecticut, USA.

Charrier A, Berthaud J (1988) Principles and methods in coffee plant breeding: Coffea canephora Pierre. In: Clarke RJ, Macrae R (eds), Coffee, Vol. 4: Agronomy, pp.167198. Elsevier Applied Science, London and New York, Great Britain.

Cilas C, Bouharmont P, Boccara M, Eskes AB, Baradat P (1998) Prediction of genetic value for coffee production in Coffea arabica from a half-diallel with lines and hybrids. Euphytica 104:49-59.

Clifford MN (1985) Chemical and physical aspects of green coffee and coffee products. In: Clifford MN, Willson $\mathrm{KC}$ (eds), Coffee: botany, biochemistry and production of beans and beverage, pp.305-374. Avi Publishing Company, Westport, Connecticut, USA.

Combes MC, Andrzejewski S, Anthony F, Bertrand B, Rovelli P, Grasiozi G, Lashermes P (2000) Characterization of microsatellite loci in Coffea arabica and related coffee species. Mol. Ecol. Notes 9:1171-1193.

Coulibaly I, Revol B, Noirot M, Poncet V, Lorieux M, Carasco-Lacombe C, Minier J, Dufour M, Hamon P (2003) AFLP and SSR polymorphism in a Coffea interspecific backcross progeny $((C$. heterocalyx $\mathrm{x} C$. canephora $) \times$. canephora). Theor. Appl. Genet. 107:1148-1155.

Crouzillat D, Rigoreau M, Bellanger L, Priyono P, Mawardi S, Syahrudi, McCarthy J, Tanksley S, Zaenudin I, Pétiard V (2004) A Robusta consensus map using RFLP and microsatellite markers for the detection of QTL. In: $20^{\text {th }}$ International Scientific Colloquium on Coffee. Bangalore, pp.546-553.

Decazy F, Avelino J, Guyot B, Perriot JI, Pineda C, Cilas C (2003) Quality of different Honduran coffees in relation to several environments. J. Food Sci. 68:2356-2361.

de Roos B, van der Weg G, Urgert R, van den Bovenkamp P, Charrier A, Katan MB (1997) Level of cafestol, kahweol, and related diterpenoids in wild species of the coffee plant Coffea. J. Agric. Food Chem. 45:3065-3069.

Dufour M, Hamon P, Noirot M, Risterucci AM, Brottier P, Vico V, Leroy T (2001) Potential use of SSR markers for Coffea spp. genetic mapping. In: $19^{\text {th }}$ International Scientific Colloquium on Coffee. Trieste, CD-ROM.
Dussert D, Lashermes P, Anthony F, Montagnon C, Trouslot P, Combes MC, Berthaud J, Noirot M, Hamon S (1999) Le caféier Coffea canephora. In : Hamon P, Seguin M, Perrier X, Glaszmann JC (eds), Diversité génétique des plantes tropicales cultivées, pp.175-194. Cirad, Montpellier, France.

Fazuoli LC, Carvalho A, Monaco LC, Texeira AA (1977) Qualidade da bebida do café ICATU. Bragantia 36:165172.

Fazuoli LC, Carvalho A, da Costa WM (1993) Hibridaçaões dialélicos no cultivar Mundo Novo de Coffea arabica. In: $19^{\circ}$ Congresso Brasileiro de Pesquisas Cafeeiras. Campinas, Brazil, pp.14-18.

FDA Food and Drug Administration (2002) Pesticide Program: Residue Monitoring 2000, May 2002. (www.cfsan.fda.gov/ dms/pes00rep.html).

Gil Fagioli S, Berry D, Bieysse D (1990) Recherches sur la résistance à Hemileia vastatrix Berk. et Br. dans un groupe de génotypes de Coffea arabica L. d'origines Ethiopiennes. Café Cacao Thé 34:105-144.

Guyot B, Petnga E, Vincent JC (1988) Analyse qualitative d'un café Coffea canephora var. Robusta en fonction de la maturité. Partie 1. Evolution des caractéristiques physiques, chimiques et organoleptiques. Café Cacao Thé 32:127-140.

Guyot B, Gueule D, Manez JC, Perriot JJ, Giron J, Villain L (1996) Influence de l'altitude et de l'ombrage sur la qualité des cafés arabica. Plant Rech. Dévelop. 3:272-283.

Harding PE, Bleeker P, Freyne DF (1987) Land Suitability evaluation for Rainfed Arabica Coffee Production: Western Highlands Province, Papua New Guinea. Coffee Res. Rep. 4. Coffee Industry Corporation, $39 \mathrm{pp}$.

ICO International Coffee Organization (2002) Coffee quality - Improvement programme - Implementation, ICC Resolution No. 407, 1 February 2002, 3 pp.

ICO International Coffee Organization (2004) Definitions for the vocabulary to describe the flavour of a coffee brew (http://www.ico.org/vocab.asp).

ISO (2000) International Standard ISO 9000: 2000. Quality management systems - Fundamentals and vocabulary, $29 \mathrm{pp}$.

ISO (2004a) International Standard ISO 9116: 2004. Green coffee - Guidelines on methods of specification, $4 \mathrm{pp}$.

ISO (2004b) International Standard ISO 10470: 2004. Green coffee - Defect reference chart, $15 \mathrm{pp}$.

ITC International Trade Centre (2002) Coffee quality, in Coffee - An exporter's guide, chap. 11, International Trade Centre UNCTAD/WTO, Geneva, pp.243-289.

Krug CA (1949) Mutações em Coffea arabica L. Bragantia 9:1-10.

Ky CL, Louarn J, Guyot B, Charrier A, Hamon S, Noirot M (1999) Relations between and inheritance of chlorogenic acid contents in an interspecific cross between Coffea pseudozanguebariae and Coffea liberica var 'dewevrei'. Theor. Appl. Genet. 98:628-637. 
Ky CL, Doulbeau S, Guyot B, Akaffou S, Charrier A, Hamon S, Louarn J, Noirot M (2000a) Inheritance of coffee bean sucrose content in the interspecific cross Coffea pseudozanguebariae x Coffea liberica 'dewevrei'. Plant Breed. 119:165-168.

Ky CL, Barre P, Lorieux M, Trouslot P, Akaffou S, Louarn J, Charrier A, Hamon S, Noirot M (2000b) Interspecific genetic linkage map, segregation distortion and genetic conversion in coffee (Coffea sp.). Theor. Appl. Genet. 101:669-676.

Ky CL, Louarn J, Dussert S, Guyot B, Hamon S, Noirot M (2001a) Caffeine, trigonelline, chlorogenic acids and sucrose diversity in wild Coffea arabica L. and $C$. canephora P. accessions. Food Chem. 75:223-230.

Ky CL, Guyot B, Louarn J, Hamon S, Noirot M (2001b) Trigonelline inheritance in the interspecific Coffea pseudozanguebariae x C. liberica var. dewevrei cross. Theor. Appl. Genet. 102:630-634.

Lashermes P, Andrzejewski S, Bertrand B, Combes MC, Dussert S, Graziosi G, Trouslot P, Anthony F (2000a) Molecular analysis of introgressive breeding in coffee (Coffea arabica L.). Theor. Appl. Genet. 100:139-146.

Lashermes P, Combes MC, Topart P, Graziosi G, Bertrand B, Anthony F (2000b) Molecular breeding in coffee (Coffee arabica L.). In: Sera T, Soccol CR, Pandey A, Roussos $\mathrm{S}$ (eds), Coffee biotechnology and quality, pp.101-112. Kluwer Academic, Dordrecht, The Netherlands.

Lashermes P, Combes MC, Prakash NS, Trouslot P, Lorieux M, Charrier A (2001) Genetic linkage map of Coffea canephora: effect of segregation distortion and analysis of recombination rate in male and female meioses. Genome 44:589-596.

Leroy T, Marraccini P, Dufour M, Montagnon C, Lashermes P, Sabau X, Ferreira LP, Jourdan I, Pot D, Andrade AC, Glaszmann JC, Vieira LGE, PiffanelliP(2005) Construction and characterization of a Coffea canephora BAC library to study the organization of sucrose biosynthesis genes. Theor. Appl. Genet. 111:1032-1041.

Lin C, Mueller LA, Mc Carthy J, Crouzillat D, Pétiard V, Tanksley S (2005) Coffee and tomato share common gene repertoires as revealed by deep sequencing of seed and cherry transcripts. Theor. Appl. Genet. 112:114-130.

Lingle TR (1986) The coffee cupper's handbook - Systematic guide to the sensory evaluation of coffee's flavor, $2^{\text {nd }}$ edition, Specialty Coffee Association of America.

Louarn J (1992) La fertilité des hybrides interspécifiques et les relations génomiques entre caféiers diploïdes d'origine africaine (Genre Coffea L. sous genre Coffea). Thèse de Doctorat d'état, Université de Paris-Sud (Orsay), France, $\mathrm{PhD}$ thesis.

Moncada P, McCouch S (2004). Simple sequences repeat diversity in diploid and tetraploid Coffea species. Genome 47:501-509.

Montagnon C, Leroy T, Yapo A (1992). Diversité génotypique et phénotypique de quelques groupes de caféiers (Coffea canephora Pierre) en collection. Conséquences sur leur utilisation en sélection. Café Cacao Thé 36:187-198.
Montagnon C, Guyot B, Cilas C, Leroy T (1998) Genetic parameters of several biochemical compounds from green coffee, Coffea canephora. Plant Breed. 117:576-578.

Montagnon C (2000). Optimisation des gains génétiques dans le schéma de sélection récurrente réciproque de Coffea canephora Pierre. ENSA Montpellier, France, $\mathrm{PhD}$ thesis.

Moreno G, Moreno E, Cadena G (1995) Bean characteristics and cup quality of the Colombia variety (Coffea arabica) as judged by international tasting panels. In: $16^{\text {th }}$ International Scientific Colloquium on Coffee. Kyoto, pp.574-583.

Moschetto D, Montagnon C, Guyot B, Perriot JJ, Leroy T, Eskes AB (1996) Studies on the effect of genotype on cup quality of Coffea canephora. Trop. Sci. 36:18-31.

N'diaye A (2005) Etude de la différenciation génétique de Coffea liberica Hiern. Cartographie génétique du croisement interspécifique entre Coffea liberica et Coffea canephora. Recherche de QTL. University of Montpellier, France, $\mathrm{PhD}$ thesis.

Netto KA, Miguel AE, Queiroz AR, Pereiran JBD (1993) Estudios de híbridos de C. arabica: Catimor versus Catuai, Catindu versus Catuai e outros. In: $19^{\circ}$ Congresso Brasileiro de Pesquisas Cafeeiras. Campinas, Brazil, pp.38-40.

Noir S, Patheyron S, Combes MC, Lashermes P, Chalhoub B (2004) Construction and characterization of a BAC library for genome analysis of the allotetraploid coffee species (Coffea arabica L.). Theor. Appl. Genet. 109:225-230.

Owuor JB (1988) An assessment of the cup quality of the new disease resistant Coffea arabica cultivar RUIRU 11 in Kenya. Kenya Coffee 53:333-336.

Paillard M, Lashermes P, Pétiard V (1996) Construction of a molecular linkage map in coffee. Theor. Appl. Genet. 93:41-47.

Pearl HM, Nagai C, Moore PH, Steiger DL, Osgood RV, Ming R (2004) Construction of a genetic map for Arabica coffee. Theor. Appl. Genet. 108:829-835.

Poncet V, Hamon P, Minier J, Carasco C, Hamon S, Noirot M (2004) SSR cross-amplification and variation within coffee trees (Coffea spp.). Genome 47:1071-1081.

Prodolliet J (2005) Coffee Quality Assurance: Current Tools and Perspectives. In: 20 ${ }^{\text {th }}$ International Scientific Colloquium on Coffee. Bangalore, pp.120-145.

Puerta GI (1998) Calidad en taza de las variedades de Coffea arabica L. cultivadas en Colombia. Cenicafé 49: 265-278.

Puerta GI (2000) Calidad en taza de algunas mezclas de variedades de café de la especie Coffea arabica L. Cenicafé 51:5-19.

Silva EA, Mazzafera P, Brunini O, Sakai E, Arruda FB, Mattoso LHC, Carvalho CRL, Pires RCM (2005) The influence of water management and environmental conditions on the chemical composition and beverage quality of coffee beans. Braz. J. Plant Physiol. 17:229-238. 
Silvarolla MB, Mazzafera P, Fazuoli LC (2004) A naturally decaffeinated arabica coffee. Nature 429:826.

Vaast P, Bertrand B, Perriot JJ, Guyot B, Génard M (2006) Fruit thinning and shade influence bean characteristics and beverage quality of $C$. arabica in optimal conditions. J. Sci. Food. Agric. 86:197-204.

Van der Vossen HAM (1985) Coffee selection and breeding. In: Clifford $\mathrm{C}$ and Wilson $\mathrm{KC}$ (eds.), Coffee: botany, biochemistry and production of beans and beverage, pp.46-68. Avi Publishing Company, Westport, Connecticut, USA.

Van der Vossen HAM (2001) Agronomy I: Coffee Breeding practices. In: Clarke RJ, Vitzthum OG (eds), Coffee: recent developments, pp.184-201. Blackwell Science, Oxford, Great Britain.

Walyaro DJ (1983) Considerations in breeding for improved yield and quality in Arabica coffee (Coffea arabica L.). Agricultural University, Wageningen, PhD thesis.

Wintgens JN (2004) Coffee: growing, processing, sustainable production. A guidebook for growers, processors, traders, and researchers, Wilet-VCG Verlag GmbH \& Co.

Yapo A, Louarn J, Montagnon C (2003) Genetic gains for yield after two back crosses of the interspecific hybrid Libusta (Coffea canephora $\mathrm{P} \times$ C . liberica Bull. Ex Hiern) to $C$. canephora P. Plant Breed. 122:288-290. 